\title{
DIE VRAAG NA NORME VIR MORALITEIT*
}

\author{
$\checkmark$ A HEYNS
}

\section{ABSTRACT}

The demand for norms for morality

This article is a short investigation of the existence and the character of norms for morality. Owing to the secularized society in which we live today the well known Martin Buber once spoke of the eclipse of the light of heaven as an eclipse of God and, we may add, an eclipse also of moral norms. A theocentríc basis for moral norms should be accepted as well as the fact that the whole of creation is subject unconditionally to his cosmonomic order. Consequently there is a concrete demand or claim on man in the situation he confronts, which cannot be reduced to an application of general moral norms to the situation concerned. God does speak to us through historical situations as well. We shall have to judge the concrete historical situation in its immediate hic et nunc call on us in the light of the will and law of God, as they are revealed to us in his Word.

1. Ons beleef 'n tyd van Godsverduistering, het die bekende Joodse wysgeer Martin Buber, by geleentheid gesê. By wyse van verklaring het hy daaraan toegevoeg: soos 'n sonsverduistering iets is wat plaasvind tussen die son en ons oë, en dus nie iets is wat in die son self gebeur nie, so is die Godsverduistering nie 'n gebeure in God self nie, maar in die mens. Die mens kort 'n geestelike oriëntering wat 'n herverskyning van God moontlik maak, sê Buber. Sekularisasie het die diepte-dimensie van die werklikheid sodanig verduister dat die dimensie van die transendente verlore gegaan het, en juis dit moet op die een of ander wyse weer herstel word. Mens moet weer daarvoor sensitief gemaak word, want wat verlore is, is nie die objektiewe werklikheid nie, maar die subjektiewe kyk op en aanvoeling vir die besondere aard van die werklikheid.

2. Na aanleiding van die gedagte van 'n Godsverduistering wil ek beweer dat ons tyd by uitstek gekenmerk word deur 'n norme-verduistering. En ook hier is dit nie iets wat in die norme as sodanig plaasvind nie, maar in die mens self. Hierdie norme-verduistering beteken konkreet dat die moderne mens sy sin en sy aanvoeling vir die normatiwiteit van sy bestaan verloor het, met ander woorde die wet van God vir die inrigting en die stilering van sy lewe, aanvaar hy nie meer nie.

3. Vir hierdie geestelike disoriëntering in die bestaan van die mens, kan 'n groot aantal oorsake genoem word. Daaronder kan die nog steeds

* Voordrag gelewer by die aktualiteitskursus oor moraliteit by die Universiteit van Pretoria, 8 Augustus 1988. 
verwildering in die hart van die mens eweneens duidelik geword. Die struktuur van die monogame huwelik, wat deur God self aan die mens gegee is, het of in poligamie verander, of word totaal geïgnoreer. Die struktuur van die staat word 'n magstiran; die struktuur van die volk 'n verslawende, en ten opsigte van ander volke, 'n afstotende lewensverband. En nie-Christelike ideologiese denkstrukture van verskillende aard, inhoud en effek, soos kommunisme, nasionaal-sosialisme en revolusionisme kom tot stand.

Kortom: die moderne mens wil in sy lewe - en dus ook in sy etiese lewe - mondig wees. Hy wil diepsinnig agter Gods bedoelinge ingryp om beter te weet; hy wil eiemagtig die sigbare en die grypbare wêreld inboor om beter te verstaan; hy wil oor die wêreld en oor sy eie lewe beter heers as wat God dit in sy openbaring aan ons gegee het om dit te doen.

6. En nou lê die bevryding van hierdie gesekulariseerde mens en die verlossing uit sy gesekulariseerde denke juis in die mens se onvoorwaardelike aanvaarding van en nougesette gehoorsaamheid aan die norme wat God vir die lewe van die mens aan die mens gegee het.

Daarom is besinning oor die norme vir moraliteit 'n dringende noodsaaklikheid in die tyd waarin ons lewe. Ek doen dit aan die hand van die volgende onderskeidinge:

\section{Skepping en orde}

1.1 Die skeppingsverhaal getuig op 'n aangrypende wyse hoe die Here God deur sy Woord nie net stof, plant, dier en mens in aansyn geroep het nie, maar hoe Hy ook orde gebring het, deurdat Hy aan elke besonderheid wat geskep is, sy spesifieke aard, plek en funksie toegeken het. Orde in die wêreld is dus nie 'n vanselfsprekende eienskap van die wêreld nie, maar' $n$ reëling van God, en uitdrukking van sy wil vir hierdie wêreld. Meer nog: ordelikheid dui nie net op die bestaan van die skepping nie, maar ook op die ontplooiende voortbestaan van die skepping op weg na sy ' einding.

1.2 Van hierdie groot en wêreldomspannende orde, is die orde in en die orde vir die mens se lewe, 'n integrale deel - al moet onmiddellik hieraan toegevoeg word dat die orde van die menslike lewe totaal anders is as dié in die res van die kosmiese wêreld. Met hierdie orde moet norme en wette nou in verband gebring word. Trouens, ons kan sê: orde is die resultaa van 'n reëling deur middel van norme en wette. 


\section{Norme en wette}

2.1 Tussen norme en wette sal duidelik onderskei moet word, al word die begrippe dikwels ook as sinonieme gebruik. Tog is daar omstandighede waar die begrip wet nie deur norm vervang kan word nie. Meestal word die term wet gebruik vir die fisiese gebeure in die natuur - waarby die fisies-biologiese aspek van die menslike bestaanswyse uiteraard ingesluit is. Só verstaan, word in ' $n$ wet dus die feitlike verloop van 'n proses waarin dieselfde oorsaak steeds dieselfde gevolg het, omskrywe. Met sy dwingende karakter is 'n wet dus onoortreebaar, en word die begrip wet, in hierdie sin, gevolglik as natuurwet verstaan.

2.2 Terwyl die begrip wet dikwels in die betekenis van norm gebruik word (so bv word die Tien Gebooie Gods Wet genoem), word die term norm uitsluitlik gebruik vir die verskeidenheid van die handelinge van die mens. Anders as die wet dwing die norm nie, maar dring hy die mens tot en vra hy van die mens gehoorsaamheid. Met sy dringende karakter is die norm dus oortreebaar, want hy veronderstel en appelleer op die moontlikheid van keuse, insig, voorkeur, beredenering en beslissing by die mens.

2.3 Omdat norme en wette dus die middele is waardeur God orde bewerk vir die kosmiese werklikheid, is die mens wat daaraan gehoorsaam is ten diepste aan God gehoorsaam, dit wil sê hy aanvaar God se handelinge met hom, hy beantwoord aan sy deur God bepaalde bestemming en hy kan deur God vir sy doel gebruik word. Maar wie ongehoorsaam is, wil nie wees wat hy in werklikheid is nie: 'n mens met wie God besig is en deur wie God wil werk.

\section{Verskeidenheid van norme}

3.1 As norme alleen geld vir menslike aktiwiteite, is dit duidelik dat daar in ooreenstemming met die verskeidenheid van menslike aktiwiteite ook 'n verskeidenheid van dienooreenstemmende norme bestaan. So kan ons praat van die norme wat geld vir die logiese, historiese, sosiaal-estetiese, juridiese, etiese en die godsdienstige. Die mens se gehoorsaamheid aan hierdie norme is die wyse waarop sy ingeskape moontlikhede tot werklikhede omskep word. Die mens wat in gehoorsaamheid op hierdie norme antwoord is op weg in die rigting van die eindgebeure waar God ten voile sal heers en alles en almal uiteindelik ten voile aan Hom gehoorsaam sal wees. En natuurlik ook omgekeerd: wie hieraan ongehoorsaam is, verduister die uitsig op die toekoms, laat God nie duidelik na vore tree nie, terwyl die ware wese van die mens nie tot openbaring kom nie. 
voortwoekerende proses van sekularisering waarskynlik as die belangrikste enkele oorsaak aangedui word. Benewens talle fasette wat dié ingewikkelde proses vertoon, lig ons slegs dié een uit wat vir ons tema van belang is, naamlik dat dit 'n ongekende magsbelewing by die moderne mens laat ontwaak het.

4. Die resultaat hiervan was tweërlei van aard: allereers het die teonome verankering van morele norme verdwyn, en vervolgens het 'n outonome verankering van morele norme in die plek daarvan verskyn. Met die verduistering van die uitsig op God wat die Bron en Oorsprong van alle norme is, het onvermydelik ook die uitsig op die bestaan van norme verdof, die insig in hulle eie-aard vertroebel, die aanvoeling vir die appêl daarvan verstomp en gevolglik het ook die gehoorsaamheid daaraan nie net verflou nie, maar in talle gevalle selfs verdwyn. Wie afskeid neem van God, neem ook afskeid van die in Hom gefundeerde en die deur Hom geproklameerde norme vir die lewe van die mens. Maar omdat die mens, kragtens sy skeppingsaard nie sonder norme kán lewe nie, het hy homself tot bron van sy eie norme verklaar. Die mens wat van God afvallig geword het, teen Hom rebelleer, sonder Hom lewe en weinig met Hom reken, het in homself ' $n$ binnekosmiese oriënteringspunt vir sy lewe en denke gevind, en met name word so'n sterk aksent op die rasionele gelê, dat die rede nie alleen die normeringsbeginsel nie, maar ook die legitimeringsbeginsel vir die mens se handelinge geword het. Al wat oorgebly het, is 'n outonomie, dit wil sê 'n in die mens self gegronde en uit die mens selfopkomende wetmatigheid, met sy onvermydelike subjektiwistiese inslag en die daarmee samehangende relatiwistiese karakter.

5. Maar met die verdwyning van die teonome en die verskyning van die outonome verankering van die morele norme, het die verwildering van die mens se lewe in prakties al die verhoudinge waarin hy staan, ingetree. In die verhouding tot die naaste ken die gesekulariseerde mens nie liefde en respek nie, maar haat en positiewe afkeer of koue afsydigheid en onverskilligheid, of egoïstiese gesentreerdheid en gevolglik uitbuiting en onderdrukking, of vrees en daarom ontvlugting. In die verhouding tot die self het hierdie mens homself tot sentrum gemaak en daardeur 'n konflikmens geword, onewewigtig in sy oordele en smake, slagoffer van sy veroweringslus, gevangene van sy begeertes. In die verhouding tot die natuur het die gedagte van 'n roeping tot die bearbeiding en bewaring daarvan verdwyn, en daaruit is ' $n$ ingesteldheid op die resultate van arbeid en inspanning gebore. In die verhouding tot die kultuur het die kultuurvorming'n daad geword waarin die mens sy eie prestasievermoë verheerlik en aanbid. Ook in die verhouding tot die strukture het die etiese 
3.2 Uiteraard is ons hier nie in al die norme geinteresseerd nie, maar alleen in die norme vir die morele lewe.

\section{Norme en moraliteit}

4.1 Op die groot uiteenlopende standpunte ten opsigte van die etimologie aangaande en die inhoud van die begrip moraliteit, gaan ons nie hier in nie. $\mathrm{Na}$ ons oordeel is die etiese of die morele ' $\mathrm{n}$ bepaalde aspek van die menslike handelinge - wat ook sy gesindheid insluit - ten opsigte van die menslike persoon. Ons sou moraliteit kon omskryf as die geheel van die mens se handelinge wat gerig is op die persoon van die mens met die $\infty$ op die verwerkliking van sy bestemming as mens. Nie alle handelinge as sodanig is morele handelinge nie. Alleen daardie handelinge wat die mens se unieke geskape uitsonderingsposisie in die wêreld raak soos dit in sy persoon tot uitdrukking kom, is morele handelinge. Daardie handelinge wat die mens, sy status en sy funksie, sy roeping en sy bestemming, sy wese en sy toerusting raak dáárdie handelinge is etiese of morele handelinge.

4.2 As die morele die wyse is waarop die persoon van die mens - dié van die ander maar ook dié van die self - behandel word, is dit duidelik dat die handelinge volgens bepaalde norme moet geskied. Geskied dit in gehoorsaamheid aan die norme is dit moreel goed en dus aanvaarbaar; geskied dit nie in gehoorsaamheid daaraan nie, is dit moreel nie goed nie en dus onaanvaarbaar.

4.3 Terwyl daar 'n hele aantal norme vir die moraliteit genoem kan word: eerbied en geregtigheid, waarheid en vrede, getrouheid en goedhartigheid, nederigheid en selfbeheersing, vreugde en vriendelikheid (vgl Eks 20, Deut 6:1-9, Lev 19:1-8, Matt 5:3-7:29, 22:37-39, Rom 13:8-10, Kol 3:1-17, Gal 5:22), kan ons tog met reg sê dat die liefde die hoogste en selfs die omvattendste norm vir die morele lewe van die mens is. Waar die persoon van die mens in liefde behandel word, daar bloei die morele lewe, en waar dit nie gebeur nie, daar kwyn die morele lewe. Juis vanweë die haas onbepaalbare rykdom van die liefdesnorm herberg hy in hom 'n verskeidenheid van norme. Maar die liefde moet gestalte en konkrete stilering kry. Trouens, sonder laasgenoemde bly die liefde ' $n$ teoretiese abstraksie. Hierheen keer ons later terug.

\section{Aard van morele norme}

5.1 Ons meen dat daar ten opsigte van die corsprong van morele norme onderskei kan word tussen geopenbaarde norme, gepositiveerde norme 
en kontingente norme.

5.2 Geopenbaarde norme. Morele norme is in die openbaring self aan die mens gegee, aangesien dit die uitdrukking is van Gods wil vir die mens se lewe. Maar daarom juis is hulle onvoorwaardelik geldig, dit wil sê hulle is nie van bepaalde voonwaardes afhanklik nie; algemeen geldig, dit wil sê alle mense is onder alle omstandighede en te alle tye gehoorsaamheid hieraan verskuldig; totaal geldig, dit wil sê die totaliteit van die ganse menslike persoon, sy wil, rede, gevoel, alles wat hy het aan geestesvermoëns, staan onder die normering van hierdie norme.

\subsection{Gepositiveerde norme}

5.3.1 Wanneer Paulus skrywe oor die lewenswandel van die Efesiërs, vermaan hy hulle om nie onverstandig op te tree nie maar, sê hy aan hulle "probeer te wete kom wat die Here wil dat julle moet doen" (Ef 5:17). En vir die Filippense bid hy om 'n toename in kennis en fyn aanvoeling, sodat hulle die dinge sal kan onderskei waarop dit werklik aankom (Fil 1:9-10). Weliswaar word Gods wil vir die morele lewe van die mens in die geopenbaarde norme uitgedruk, maar 'n volledige, gesistematiseerde en op die huidige omstandighede van die mens afgestemde openbaring is dit nie. Dit beteken dat die mens, in 'n steeds lewende omgang met Gods Woord, die geopenbaarde wil van God moet ontvou in 'n proses van fyner en konkreter formuleringe met die oog op gebruik vir en realisering in die groot verskeidenheid van lewensterreine, lewensaktiwiteite en lewensituasies.

5.3.2 'n Konkrete voorbeeld: uit die openbaring is dit duidelik dat seksuele gemeenskap binne die monogame huwelik vir voortplanting noodsaaklik is. Maar wat is die etiese norme ten opsigte van die moderne tegniese moontlikheid van kunsmatige inseminasie met die saad van die eggenoot of selfs van iemand anders? Daaroor laat die Skrif hom nie eksplisiet uit nie, maar uit die geopenbaarde norme moet norme ook vir dié menslike handelinge afgelei of gepositiveer word. Dit behoort duidelik te wees dat aan hierdie soort norme met die voortskrydende tegniese ontwikkelinge 'n al hoe groter behoefte sal ontstaan. Nog enkele voorbeelde: watter norm of norme geld vir die vrou in die amp, of vir die beoordeling van pornografie in die literatuur, of vir die aanwending van naaktheid in die kuns? Maar dit is verder ook duidelik dat die normatiewe gelding van die deur die mens gepositiveerde norme, alleen geleë is in hulle ooreenstemming met die geopenbaarde norme. Alle verstaan, formulering en realisering van die gepositiveerde norme bly dus steeds onderworpe aan die kritiese toetsing en korrigering deur die geopenbaarde norme. 'n Interessante voor- 
beeld van die verskil in etiese waardering van gepositiveerde norme, is die praktyk (nou afgeskaf) van bonusobligasies. Sommige individuele gelowiges en selfs kerke het dit eties aanvaarbaar gevind, terwyl ander dit eties veroordeel het.

\subsection{Kontingente norme}

5.4.1 Die werklikheid waarin die mens leef en waarvan hy self deel is, is 'n deur die Voorsienigheidswoord van God gestempelde werklikheid. Daarom leef ons nie in 'n wêreld net met suiwer feite of suiwer gebeurtenisse nie, maar in en deur die feite en die gebeurtenisse tree die werklikheid die mens aansprekend en opeisend tegemoet. Die mens weer, wat natuurlik self deel is van hierdie werklikheid, vertoon 'n affiniteit vir en 'n bepaalde kreatiwiteit met betrekking tot die normatiewe strukturering van die deur die Woord bepaalde werklikheid.

5.4.2 Vanuit elke konkrete situasie word 'n plig op die mens gelê om te handel. Dat elke situasie nie spraakloos is nie, maar met sy behorenseise na die mens kom, hoor ons byvoorbeeld in die bekende woorde van die Prediker: God het aan die mens 'n taak gegee, en daarom is daar vir alles 'n tyd: 'n tyd om gebore te word en 'n tyd om te sterwe, 'n tyd om te plant en 'n tyd om uit te roei wat geplant is ... (Pred 3). Wanneer die bestemde tyd God se bestemde tyd - vir die mens aanbreek, moet die mens weet wát gedoen moet word en hoé dit gedoen moet word. 'n Duidelike voorbeeld van kontingente norme is Paulus se advies insake die huwelik: enersyds sê hy dat dit goed is vir 'n man om sonder 'n vrou te lewe ( 1 Kor 7:1), want die ongetroude man kan aandag gee aan die dinge van die Here (vs 32); andersyds kan 'n man trou weens die gevare van onsedelikheid (vs 2). Maar nou is die vraag: gesien in die lig van Paulus se "advies", wat moet ék nou doen in mý omstandighede - trou of nie trou nie? Paulus se opmerkinge help mý nie. Ek sal vir myself moet uitmaak of ek gaan trou en of ek nié gaan trou nie, en as ek gaan trou sal ek self moet besluit wanneer die tyd daarvoor aangebreek het. Die huwelik is ongetwyfeld 'n roeping, maar is dit ook vir mý 'n roeping? Eweneens is dit 'n roeping om kinders in die wêreld te bring, maar is dit ook vir mý 'n roeping? As Paulus elders sê dat van elke geleentheid die beste gebruik gemaak moet word (Ef 5:15), dan is dit die geleentheid self wat die inhoud en die aard van die beste medebepaal - uiteraard natuurlik ook die kennis en die fyn aanvoeling van die gelowige om die dinge te kan onderskei waarop dit werklik aankom (Fil 1:9-10).

5.4.3 Nooit mag die kontingente norme van die gepositiveerde en van die 
geopenbaarde norme losgemaak word nie. Steeds gaan dit om die vraag van Gods wil vir my lewe, steeds moet sy raadsplan op aarde gerealiseer word, steeds moet die lewe van die mens met die oog op sy roepingsvervulling bevorder en vergemaklik word. Die geopenbaarde norme is die blywende bron en rigsnoer van alle morele handelinge. Maar dan moet dit steeds gaan om norme vir hierdie mense in hierdie omstandighede.

5.4.4 Ons illustreer hierdie samehang met 'n enkele voorbeeld. Naasteliefde is 'n geopenbaarde norm vir die morele lewe. Maar wie my naaste is wat ek moet liefhê, en hoe ek moet liefhê, word vir my eers duidelik in die behorenseis van die konkrete situasie waarin ek my bevind: die vrou met wie ek getroud is, het ek anders lief as my buurvrou met wie ek op 'n vriendskaplike voet verkeer, of as die vrou wat my sekretaresse is met wie ek'n saaklike verhouding het, of die vrou wat my verpleeg en moontlik in 'n barmhartigheidsverhouding tot my staan. Nie een van hierdie vier gestaltes van die liefde mag tot die ander herlei word nie, en tog word al vier deur die algemene norm van die liefde genormeer en is legitieme gestaltes daarvan.

\section{Ten slotte}

1. Daar heers grenslose verwarring en onsekerheid oor morele norme. Daarom ook verkeer die morele lewe van baie van ons mense in 'n uiters ernstige krisis. Ons het gepraat van 'n norme-verduistering. Ons mense sal intensief opgevoed moet word ten opsigte van die diepste wese van menswees, ten opsigte van die roeping van die mens om in al sy handelinge moreel verantwoord op te tree en elkeen moet sy verantwoordelikheid teenoor die gemeenskap besef.

2. Natuurlik is die kerk die belangrikste voedingsruimte vir die morele. Meer as ooit tevore sal die morele dimensie van die menslike handelinge daar beklemtoon moet word. Die kerk sal nie alleen die onmisbaarheid van morele norme vir die gesonde ontplooing van die mens se lewe moet beklemtoon nie. Hy sal 'n groter sensitiwiteit en verantwoordelikheid ten opsigte van die formulering van gepositiveerde en kontingente norme moet aandui, maar ook morele probleme soos seksualiteit, oorlog, lone, en mens- en volkereverhoudinge aan die orde moet stel. Terselfdertyd sal die kerk nie mag terugdeins om mense kundig op hoogte te bring met die wêreld waarin hulle lewe en waarin hulle moet handel nie. Geestesstrominge wat die prinsipiële agtergrond vorm van denk- en lewenspatrone, en dikwels in morele beskouinge en morele handelinge vergestalting vind, sal ook aandag moet kry. 
3. Maar die kerk is natuurlik nie die enigste voedingsruimte vir die morele nie. Daar is uiteraard ook nog te noem: die persoonlike omgang met en volhardende studie van die Skrif; die gesin, skool, universiteit, die massakommunikasiemedia. Kortom: al die samelewingsverbande in die ganse samelewing sal gemobiliseer moet word ten einde die mens se geestelike antenne vir morele norme te herstel.

\section{BIBLIOGRAFIE}

Abbing, P J Roscam, Om de mens. Ethiek in wetenschap en beroep, Leiden 1968.

Barth, K, K.D. 111/4, Zollikon 1951.

Dooyeweerd, $H$, Vernieuwing en bezinning, Zutphen 1959.

Du Rand, J A , Entoié in die Johannesevangelie en -briewe, DD-proefskrif, Universiteit van Pretoria 1977.

Heyns, J A, Teologiese Etiek deel 1, Pretoria 1982.

Kleinknecht, Theologische Wörterbuch zum Neuen Testament, 4. Stuttgart 1942.

Loen, A E, De Vaste Grond, Amsterdam 1946.

Olthuis, J H. Facts, values and ethics, Assen 1969.

Rahner, H, Man at play. Did you ever practice eutrapelia? London 1963.

Søe, N H, Christliche Ethik, München, 1965.

Stoker, H G, Beginsels en metodes in die wetenskap, Potchefstroom 1961.

Stoker, H G, Oorsprong en rigting, Bd 1 en 2. Kaapstad 1967.

Thierry, H., De bedreigde mens in de moderne sameleving, 's-Gravenhage 1956.

Troost, A, Geen aardse macht begeren wij, Amsterdam, 1976.

Van Riessen, H, "Betekenis van de Wetsidee in de Wijsbegeerte", in: Phil. Reformata, 30e jrg 1965. 